\title{
Effect of Butyric Acid Supplementation on Growth Performance and Immune Response in Broilers
}

\author{
D. Nataraja*, V. Malathi, Jayanaik, H. C. Indresh and J. N. Sreedhara
}

Department of Poultry Science, Veterinary college, Hebbal, Bengaluru- 560024, Karnataka Veterinary, animal and Fisheries Sciences University, Karnataka, INDIA, India

*Corresponding author

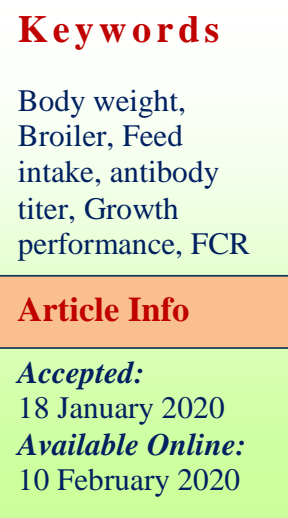

\section{Introduction}

Due to growing concerns about antibiotic resistance and the potential ban for antibiotic growth promoters in many countries, there is an increasing interest in finding alternative to antibiotics in poultry production (Patterson and Burkholder, 2003; Chichlowski et al., 2007). The possible alternatives to antibiotics for growth promotion and improvement of feed efficiency in poultry are dietary supplementation of probiotic, prebiotic, feed enzymes, phytobiotics, essential oils and organic acids (Jin et al., 1997; Xu et al., 2006; Biggs et al., 2007). Amongst the organic acids, short chain fatty acids (SCFA) are considered as potential alternative to antibiotic growth promoters (Van Immerseel 
et al., 2005). Butyric acid is a SCFA, which has higher bactericidal activity when the acid is undissociated (Leeson, 2007). Bacterial cell take up undissociated fatty acids and once these acids dissociate, there is change in the intracellular $\mathrm{pH}$ leading to death of bacterial cells.

Supplementation of butyric acid derivatives in the diets of broiler chickens could replace antibiotics while maintaining growth performance (Namkung et al., 2011), decrease infection by Salmonella enteritidis (Fernandez-Rubio et al., 2009), and increase growth performance under stress (Zhang et al., 2011).

\section{Materials and Methods}

\section{Dietary treatments and management}

In the present experiment, 600 day old straight run broiler chicks of uniform body weight were procured from a commercial hatchery.All the chicks were wing banded for identification, weighed and divided randomly into 24 replicates of 25 chicks each. Each of the 4 dietary treatments groups were allotted with 6 replicates. The chicks were reared in open sided house under deep litter system with all standard management practices till 6 weeks of age. Birds were fed (NRC, 1994, Table. 1) with broiler pre starter diet (1-7 days), starter diet (8-21 days) and finisher diet (22-42 days).

Chicks were provided ad libitum supply of feed and water throughout the study. Feeding of test diets commenced from day one and continued till the termination of experiment at six weeks of age. The experimental chicks were vaccinated against Newcastle Disease on day seven with Lasota strain and against Infectious Bursal Disease on day 14 with Intermediate strain through intra ocular route. Booster doses against ND and IBD were given on $21^{\text {st }}$ day and $28^{\text {th }}$ day with F1 and intermediate strains, respectively. All the procedures followed during the trial were approved by the Institutional animal ethical committee, Veterinary College, Bengaluru, KVAFSU.

\section{Growth performance}

The body weight of individual birds was recorded at the beginning of the experiment and at the end of each week till six weeks of age to monitor the pattern of body weight gain. The weighing of the birds was done in the early hours of the day before feeding using digital electronic pan topbalance. The daily amount of the concerned diet was weighed and offered separately to each replicate.

At the end of each week, the amount of feed left out in the feeder was removed and weighed carefully without any spillage. Based on the amount of feed given and the left out feed, weekly feed consumption was calculated replicate wise till the end of six weeks. Based on the feed intake per week, the average cumulative feed intake per bird was calculated. The feed conversion ratio (FCR) expressed as the ratio of amount of feed consumed $(\mathrm{kg})$ to the body weight $(\mathrm{kg})$ under each experimental group per week and also on cumulative basis was determined.

\section{Immune response}

The serum samples collected on 21st and 42nd days were assayed for antibody titers against Newcastle disease virus (NDV) and Infectious bursal disease virus (IBDV) using Haemagglutination Inhibition testand ELISA, respectively. The micro-test method described by Allan and Gough (1974) was used for detection of $\mathrm{HI}$ titer from serum samples collected on 21 st and 42nd day to assess the antibody titer. 
Table.1 Per cent ingredient and nutrient composition of basal experimental diet

\begin{tabular}{|c|c|c|c|}
\hline Ingredients & $\begin{array}{l}\text { Prestarter } \\
\text { (1-7 days) }\end{array}$ & $\begin{array}{l}\text { Starter } \\
\text { (8-21 days) }\end{array}$ & $\begin{array}{l}\text { Finisher } \\
\text { (22-42 days) }\end{array}$ \\
\hline Yellow maize & 52.17 & 56.47 & 58.90 \\
\hline Soya bean meal & 40.9 & 35.54 & 32 \\
\hline Vegetable oil & 3.00 & 4.3 & 4.3 \\
\hline Dicalcium phosphate & 1.50 & 1.00 & 0.70 \\
\hline Common salt & 0.40 & 0.35 & 0.35 \\
\hline Mineral mixture* & 1.50 & 1.90 & 1.90 \\
\hline Vitamin premix $* *$ & 0.20 & 0.10 & 0.10 \\
\hline DL-Methionine & 0.20 & 0.15 & 0.15 \\
\hline Vit.B complex with $E^{* * *}$ & 0.05 & 0.10 & 0.10 \\
\hline Antibiotic & 0.03 & 0.03 & 0.0 \\
\hline Coccidiostat & 0.05 & 0.05 & 0.0 \\
\hline \multicolumn{4}{|l|}{ Nutrient composition } \\
\hline Crude Protein (\%) ${ }^{b}$ & 22.63 & 18.92 & 20.45 \\
\hline Crude Fat (\%) ${ }^{b}$ & 1.47 & 4.23 & 4.95 \\
\hline Crude Fibre (\%) ${ }^{b}$ & 3.39 & 3.51 & 3.73 \\
\hline Moisture (\%) & 13.29 & 10.81 & 10.07 \\
\hline $\operatorname{Ash}(\%)^{b}$ & 6.86 & 6.54 & 6.23 \\
\hline Calcium $(\%)^{\mathrm{a}}$ & 1.03 & 1.01 & 0.97 \\
\hline Phosphorous (\%) ${ }^{\text {a }}$ & 0.457 & 0.453 & 0.424 \\
\hline
\end{tabular}

*Mineral mixture: Each 100 g contains Calcium- $30 \%$, Phosphorus- $9 \%$, Manganese- $0.4 \%$, Zinc- $0.4 \%$, Iron2000 ppm, Copper- 500 ppm, Iodine- 100 ppm and Selenium- 23 ppm.

**Vitamin premix: Each gram contains Vitamin A - 82,500 IU, Vitamin $\mathrm{B}_{2}-50 \mathrm{mg}$, Vitamin $\mathrm{D}_{3}-12,000 \mathrm{IU}$ and Vitamin K - $10 \mathrm{mg}$.

***Vit.B complex with E: Each gram contains Vitamin $\mathrm{B}_{1^{-}} 4 \mathrm{mg}$, Vitamin $\mathrm{B}_{6^{-}} 8 \mathrm{mg}$, Vitamin $\mathrm{B}_{12}-40 \mathrm{mcg}$, Vitamin E- $40 \mathrm{mg}$, Calcium D pantothenate- $40 \mathrm{mg}$ and Niacin-60 mg.

${ }^{\mathrm{a}}$ calculated values; ${ }^{\mathrm{b}}$ analyzed value

The HI test was done manually by $\beta$ procedure in ' $U$ ' bottom micro-plates using diluters, droppers and 4 HA units of ND viral antigen. The antibody titer against IBDV was measured using Poultry Diagnostic and Research Centre (PDRC) indirect ELISA Kit.
Each of the steps was followed as per the manufacturer's instructions. The weight of immune organs (spleen, thymus and bursa of Fabricius) of birds supplemented with basal diet and graded levels of butyric acid was measured on 21st and 42nd days of the trail. 


\section{Statistical analysis}

The data was subjected to One-way analysis of variance (ANOVA) using SPSS statistical software (Version 20 for windows, SPSS). Values were expressed as mean \pm SE. Means were compared by Duncan's test to determine significance between treatments. Significance of difference between treatments means was determined at the $\mathrm{P} \leq 0.05$.

\section{Results and Discussion}

\section{Effect of butyric acid on growth performance}

The effects of butyric acid supplementation on growth performance of broiler chickens are presented in Table 2. At six weeks of age, the body weight was significantly higher in butyric acid supplemented groups when compared to the control group.

However, there was no significant difference in body weight among the groups supplemented receiving different levels of butyric acid. Butyric acid supplementation had no significant effect on the feed intake and feed conversion ratio of broilers.

The higher body weight recorded at six weeks of age could be due to improvement in protein and energy digestibility, reducing host nutrients and endogenous nitrogen losses, lowering sub-clinical infections, reducing the production of ammonia and other growth depressing microbial metabolites (Dibner and Buttin, 2002).

In the present study, the improvement in FCR could be attributed to significantly higher body weight due to better intestinal health and high digestibility of nutrients in broilers, which are extremely important in order to attain higher body weight and better FCR (Roberts et al., 2015).

\section{Effect of butyric acid on Immune response}

\section{Antibody titer}

The effect of butyric acid on the antibody titer against Newcastle disease virus (NDV) and Infectious bursal disease virus (IBDV) on both 21 and 42 days is presented in Table 3 . In the present study the antibody titer was not influenced by butyric acid supplemented on both phases of the trail. Imran et al. (2017) supplemented graded levels of micro encapsulated butyric acid $(0.025,0.035$ and $0.045 \%)$ and noted no effect on antibody titer against NDV and similar findings were reported by Sikander et al. (2017). Jahanian (2011) reported 0.2 per cent butyric acid glycerides supplementation improved the ND titer at $12^{\text {th }}$ day post vaccination.

\section{Immune organs weight}

The effect of butyric acid on immune organs weight as per cent body weight on day 21 and 42 is depicted in Table 4. The weight of spleen and bursa of Fabricius were not affected by dietary supplementation of butyric acid on both phases of the study. The weight of thymus was not influenced by butyric acid supplementation on dad 21 and showed significantly lower weight in butyric acid supplemented groups compared to the control group on day 42. Except for the thymus weight, other immune organ weights in the current study were not affected by butyric acid supplementation. This correlates well with the antibody titer against NDV and IBDV which were also not affected with BA supplementation. These findings are in agreement with Mahadavi and Torki (2009) who supplemented butyric acid (0.2 and 0.3 $\%$ ) in broilers diet and found no effect on immune organs weight and also by Imran et al. (2017) who supplemented graded levels of micro encapsulated butyric acid $(0.025,0.035$ and $0.045 \%$ ) and found no effect on immune organs was noticed. 
Table.2 Effect of butyric acid Supplementation on body weight in broiler chicken

\begin{tabular}{|c|c|c|c|c|c|c|}
\hline \multirow[t]{2}{*}{ Treatment Group } & \multicolumn{6}{|c|}{ Weekly Body weight (g/bird/week) } \\
\hline & $\mathbf{I}$ & II & III & IV & $\mathbf{V}$ & VI \\
\hline $\begin{array}{l}\text { Basal diet } \\
\text { (Control) }\end{array}$ & $149.03 \pm 1.47^{b}$ & $386.29 \pm 4.24^{b}$ & $729.72 \pm 8.10^{c}$ & $1174.25 \pm 11.99^{b}$ & $1745.25 \pm 19.11^{b}$ & $2349.53 \pm 25.43^{b}$ \\
\hline $\begin{array}{c}\text { Basal diet }+0.1 \% \\
\text { butyric acid }\end{array}$ & $152.15 \pm 1.64^{\mathrm{ab}}$ & $398.52 \pm 4.60^{a}$ & $770.50 \pm 8.99^{b}$ & $1250.69 \pm 14.53^{a}$ & $1801.17 \pm 18.44^{\mathrm{a}}$ & $2422.17 \pm 27.59^{\mathrm{ab}}$ \\
\hline $\begin{array}{l}\text { Basal diet }+0.2 \% \\
\text { butyric acid }\end{array}$ & $153.34 \pm 1.34^{\mathrm{ab}}$ & $400.41 \pm 4.16^{\mathrm{a}}$ & $766.74 \pm 7.40^{b}$ & $1255.34 \pm 13.13^{a}$ & $1825.79 \pm 20.37^{\mathrm{a}}$ & $2458.09 \pm 29.81^{\mathrm{a}}$ \\
\hline $\begin{array}{c}\text { Basal diet }+0.4 \% \\
\text { butyric acid }\end{array}$ & $156.09 \pm 1.55^{\mathrm{a}}$ & $407.36 \pm 4.24^{\mathrm{a}}$ & $813.43 \pm 8.55^{a}$ & $1279.00 \pm 13.86^{\mathrm{a}}$ & $1831.66 \pm 19.08^{\mathrm{a}}$ & $2485.38 \pm 25.88^{a}$ \\
\hline P value & 0.011 & 0.006 & 0.000 & 0.000 & 0.006 & 0.003 \\
\hline
\end{tabular}

Table.3 Effect of butyric acid Supplementation on feed consumption in broiler chicken

\begin{tabular}{|c|c|c|c|c|c|c|}
\hline Treatment Group & \multicolumn{5}{|c|}{ Weekly Feed Consumption (g/bird/week) } \\
\cline { 2 - 7 } & I & II & III & IV & V & VI \\
\hline $\begin{array}{c}\text { Basal } \\
\text { diet(Control) }\end{array}$ & $131.37 \pm 4.06$ & $554.32 \pm 3.12$ & $1213.86 \pm 17.31$ & $2176.88 \pm 20.66$ & $3211.43 \pm 30.77$ & $4617.85 \pm 37.34$ \\
\hline $\begin{array}{c}\text { Basal diet + 0.1\% } \\
\text { butyric acid }\end{array}$ & $131.90 \pm 2.62$ & $564.10 \pm 4.80$ & $1185.71 \pm 25.49$ & $2178.10 \pm 29.58$ & $3232.96 \pm 24.51$ & $4647.42 \pm 39.02$ \\
\hline $\begin{array}{c}\text { Basal diet + 0.2\% } \\
\text { butyric acid }\end{array}$ & $135.80 \pm 3.86$ & $559.38 \pm 2.16$ & $1185.36 \pm 25.90$ & $2160.73 \pm 19.97$ & $3212.99 \pm 20.43$ & $4607.09 \pm 31.47$ \\
\hline $\begin{array}{c}\text { Basal diet + 0.4\% } \\
\text { butyric acid }\end{array}$ & $133.72 \pm 3.32$ & $557.22 \pm 3.06$ & $1193.33 \pm 10.80$ & $2180.16 \pm 12.21$ & $3214.88 \pm 22.78$ & $4607.99 \pm 37.55$ \\
\hline P value & 0.806 & 0.258 & 0.746 & 0.914 & 0.921 \\
\hline *Values are means \pm standard error & & & & 0.848 \\
\hline
\end{tabular}

*Values are means \pm standard error 
Table.4 Effect of butyric acid Supplementation on feed conversion ratio in broiler chicken

\begin{tabular}{|c|c|c|c|c|c|c|}
\hline \multirow[t]{2}{*}{ Treatment Group } & \multicolumn{6}{|c|}{ Weekly FCR } \\
\hline & I & II & III & IV & V & VI \\
\hline Basal diet (Control) & $1.28 \pm 0.04$ & $1.43 \pm 0.03^{\mathrm{a}}$ & $1.66 \pm 0.03^{\mathrm{a}}$ & $1.85 \pm 0.01^{a}$ & $1.84 \pm 0.02^{\mathrm{a}}$ & $1.96 \pm 0.02$ \\
\hline $\begin{array}{c}\text { Basal diet }+0.1 \% \\
\text { butyric acid }\end{array}$ & $1.25 \pm 0.02$ & $1.41 \pm 0.00^{\mathrm{ab}}$ & $1.54 \pm 0.03^{b}$ & $1.74 \pm 0.02^{b}$ & $1.80 \pm 0.01^{\mathrm{ab}}$ & $1.93 \pm 0.02$ \\
\hline $\begin{array}{c}\text { Basal diet }+0.2 \% \\
\text { butyric acid }\end{array}$ & $1.27 \pm 0.05$ & $1.39 \pm 0.01^{\mathrm{ab}}$ & $1.54 \pm 0.02^{b}$ & $1.72 \pm 0.01^{b}$ & $1.76 \pm 0.01^{b}$ & $1.89 \pm 0.03$ \\
\hline $\begin{array}{c}\text { Basal diet }+0.4 \% \\
\text { butyric acid }\end{array}$ & $1.21 \pm 0.04$ & $1.36 \pm 0.01^{b}$ & $1.47 \pm 0.03^{b}$ & $1.70 \pm 0.02^{b}$ & $1.77 \pm 0.03^{\mathrm{ab}}$ & $1.87 \pm 0.04$ \\
\hline P value & 0.700 & 0.161 & 0.004 & 0.001 & 0.122 & 0.232 \\
\hline
\end{tabular}

*Values are means \pm standard error. Means within each column with different superscript differ significantly $(\mathrm{P} \leq 0.05)$

Table.5 Effect of Butyric acid supplementation on Antibody titers against New Castle Disease Virus and Infectious Bursal Disease Virus in broiler chicken

\begin{tabular}{|c|c|c|c|c|}
\hline Treatment Group & \multicolumn{2}{|c|}{$\mathbf{2 1}^{\text {st }}$ Day } & \multicolumn{2}{|c|}{$\mathbf{4 2}^{\text {nd }}$ Day } \\
\hline & $\mathbf{L o g}_{\mathbf{1 0}}$ NDV titer & IBDV titer & Log $_{\mathbf{1 0}}$ NDV titer & IBDV titer \\
\hline Basal diet (Control) & $40.66 \pm 12.62$ & $1453.08 \pm 109.58$ & $4.66 \pm 1.13$ & $1632.66 \pm 117.16$ \\
\hline $\begin{array}{c}\text { Basal diet + 0.1\% } \\
\text { butyric acid }\end{array}$ & $19.16 \pm 6.56$ & $1435.00 \pm 64.07$ & $3.50 \pm 0.74$ & $1557.83 \pm 125.82$ \\
\hline $\begin{array}{c}\text { Basal diet + 0.2\% } \\
\text { butyric acid }\end{array}$ & $30.00 \pm 10.75$ & $1227.83 \pm 85.01$ & $3.16 \pm 0.75$ & $1619.83 \pm 83.79$ \\
\hline $\begin{array}{c}\text { Basal diet + } \mathbf{0 . 4 \%} \\
\text { butyric acid }\end{array}$ & $23.00 \pm 7.47$ & $1510.25 \pm 166.53$ & $4.00 \pm 0.95$ & $1571.25 \pm 123.79$ \\
\hline P value & 0.352 & 0.325 & & 0.676 \\
\hline
\end{tabular}

*Values are means \pm standard error 
Table.6 Effect of Butyric acid supplementation on Immune organs weight

(as per cent of body weight) in broiler chicken

\begin{tabular}{|c|c|c|c|c|c|c|}
\hline \multirow[t]{2}{*}{ Treatment Group } & \multicolumn{3}{|c|}{$21^{\text {st }}$ Day } & \multicolumn{3}{|c|}{$42^{\text {nd }}$ Day } \\
\hline & Spleen & Thymus & $\begin{array}{l}\text { Bursa of } \\
\text { Fabricius }\end{array}$ & Spleen & Thymus & Bursa of Fabricius \\
\hline Basal diet (Control) & $0.03 \pm 0.003$ & $0.10 \pm 0.009$ & $0.06 \pm 0.004$ & $0.14 \pm 0.012$ & $0.42 \pm 0.027^{\mathrm{a}}$ & $0.07 \pm 0.014$ \\
\hline $\begin{array}{c}\text { Basal diet }+0.1 \% \text { butyric } \\
\text { acid }\end{array}$ & $0.04 \pm 0.002$ & $0.11 \pm 0.008$ & $0.06 \pm 0.009$ & $0.12 \pm 0.005$ & $0.32 \pm 0.020^{b}$ & $0.07 \pm 0.011$ \\
\hline $\begin{array}{c}\text { Basal diet }+0.2 \% \text { butyric } \\
\text { acid }\end{array}$ & $0.04 \pm 0.003$ & $0.12 \pm 0.013$ & $0.05 \pm 0.003$ & $0.12 \pm 0.007$ & $0.30 \pm 0.025^{b}$ & $0.07 \pm 0.012$ \\
\hline $\begin{array}{c}\text { Basal diet }+0.4 \% \text { butyric } \\
\text { acid }\end{array}$ & $0.04 \pm 0.002$ & $0.13 \pm 0.013$ & $0.07 \pm 0.007$ & $0.14 \pm 0.008$ & $0.36 \pm 0.033^{a b}$ & $0.05 \pm 0.003$ \\
\hline P value & 0.603 & 0.451 & 0.319 & 0.103 & 0.025 & 0.585 \\
\hline
\end{tabular}

*Values are means \pm standard error. Means within each column with different superscript differ significantly $(\mathrm{P} \leq 0.05)$

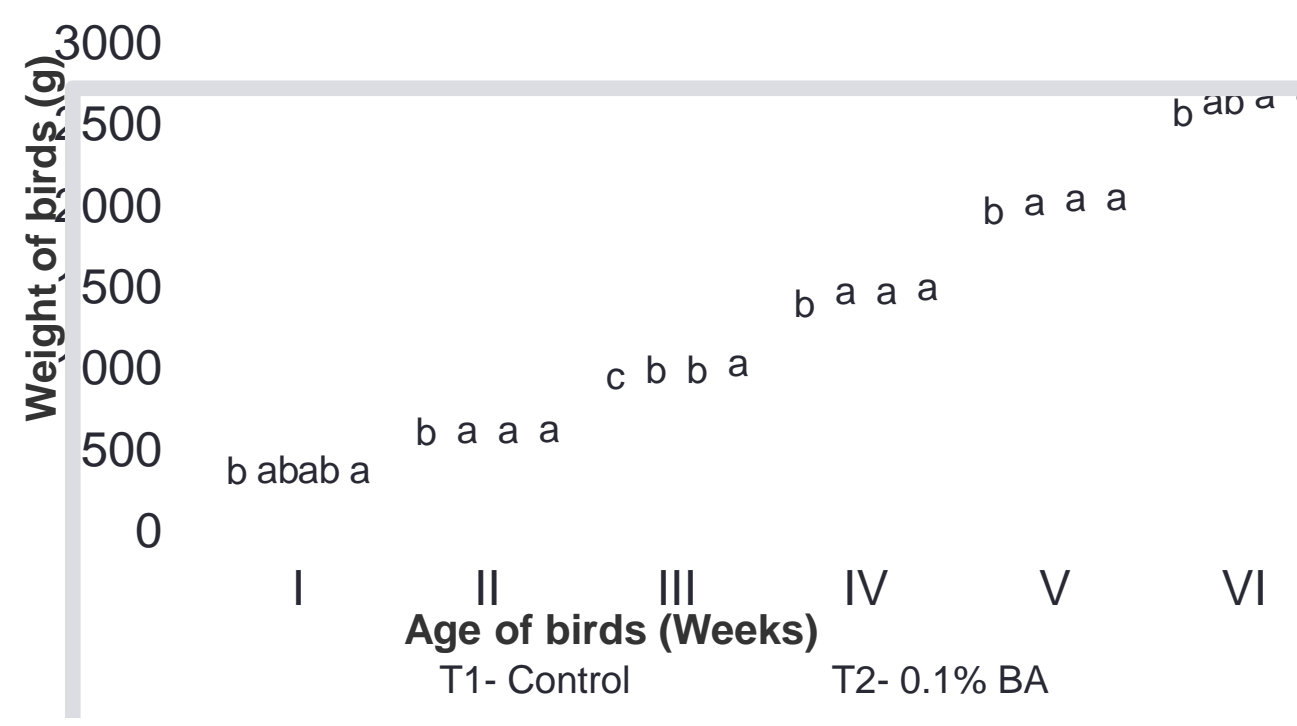




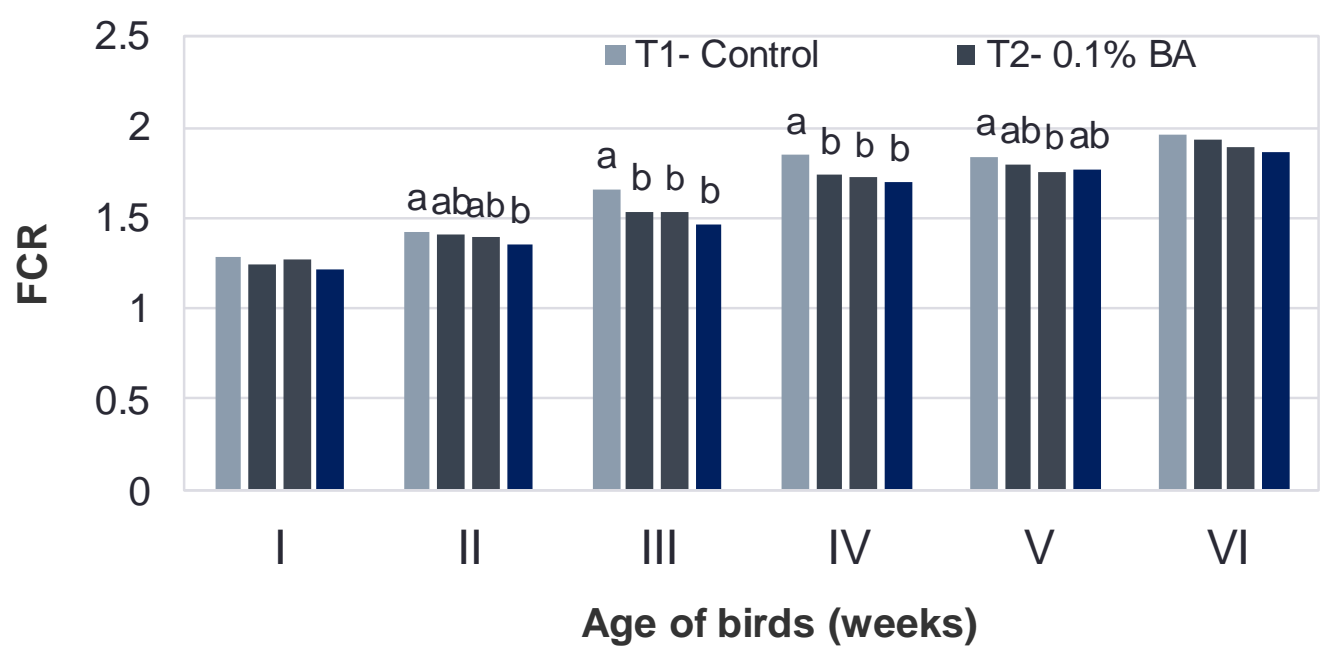

Fig.1 Effect of butyric acid supplementation on body weight and FCR in broiler chicken

From the results of the present study, it can be concluded that the growth performance and feed conversion efficiency in broiler chicken could be improved by supplementation of butyric acid. However, butyric acid supplementation did not show any positive effect on immune response in broilers.

\section{References}

Allan, W.H. and Gough, R.E. 1974. A standard haemagglutination inhibition test for Newcastle disease. A comparison of macro and micro methods. Veterinary Record, 95(6):120123.

Biggs, P., Parsons, C.M. and Fahey, G.C. 2007. The effects of several oligosaccharides on growth performance, nutrient digestibilities, andcecal microbial populations in young chicks. Poult. Sci. 86: 23272336.

Chichlowski, M., Croom, J., Mcbride,B.W., Daniel, L., Davis, G. and Kaci, M.D. 2007. Direct-fed microbial primalc and Salinomycin modulate whole body and intestinal oxygen consumption and intestinal mucosal cytokine production in the broiler chick. Poult. Sci. 86:
1100-1106.

Dibner, J.J. and Buttin, P. 2002. Use of organic acids as a model to study the impact of gut microflora on nutrition and metabolism. J. Appl. Poult. Res. 11(4): 453-463.

Fern’Andez-Rubio, C., Ord'Õnez, C., AbadGonz'Alez, J., Garcia-Gallego, A., Honrubia, M. P., Mallo, J. J. and Bala na-Fouce, R. 2009. Butyric acidbased additives help protect broiler chickens from Salmonella enteritidis infection. Poult. Sci. 88:943-948.

Imran, M., Ahmed, S., Ditta, Y.A., Mehmood, S., Rasool, Z. and Zia, M.W. 2017. Effect of Microencapsulated Butyric Acid supplementation on growth performance, ileal digestibility of protein, gut health and immunity in Broilers. Indian J. Anim. Res.: 1-5.

Jahanian, R. 2011. Effect of varying levels of butyric acid glycerides on performance, immune responses and jejuna epithelium morphology of broiler chicks. In 18th European Symposium on Poultry Nutrition, Izmir, Turkey. : 213-215.

Jin, L.Z., Ho, Y.W., Abdullah, N. and Jalaludin, S. 1997. Probiotics in poultry: 
modes of action. World's Poult. Sci. 53(4):351-368.

Lesson, S. 2007. Butyratelancing science versus societal issues in poultry nutrition. Nutr. Abstr. Rev. (B). 71:1-5.

Mahdavi, R. and Torki, M. 2009. Study on Usage Period. of Dietary Protected Butyric Acid on Performance. Carcass Characteristics. Serum Metabolite Levels and Humoral Immune Response of Broiler Chickens. J. Anim. and Vet. Adv., 8(9): 1702-1709.

Namkung, H., Yu, H., Gong, J. and Leeson, S. 2011. Antimicrobial activity of butyrate glycerides toward Salmonella Typhimurium and Clostridium perfringens. Poult. sci. 90(10):22172222.

NRC, (1994). Nutrient Requirements of Poultry. 9th rev. Edn. National Academy Press, Washington.

Patterson, J.A. and Burkholder, K. 2003.Application of prebiotics and probiotics in poultry production. Poult. Sci. 82:627-631.

Roberts, T., Wilson, J., Guthrie, A., Cookson, K., Vancraeynest, D., Schaeffer, J., Moody, R. and Clark, S. 2015. New issues and science in broiler chicken intestinal health: Emerging technology and alternative interventions. $J$. Appl.Poult. Res.24(2):257-266.

Sikandar, A., Zaneb, H., Younus, M., Masood, S., Aslam, A., Khattak, F., Ashraf, S., Yousaf, M.S. and Rehman, H. 2017. Effect of sodium butyrate on performance, immune status, microarchitecture of small intestinal mucosa and lymphoid organs in broiler chickens. Asian-Aust. J. anim. sci. 30(5):690-699.

Van Immerseel, F., Boyen, F., Gantois, I., Timbermont, L., Bohez, L., Pasmans, F., Haesebrouck, F. and Ducatelle, R. 2005. Supplementation of coated butyric acid in the feed reduces colonization and shedding of salmonella in poultry. Poult. Sci. 84:1851-1856.

Xu, C-L., Ji, C., Ma, Q., Hao, K., Jin, Z.Y. and $\mathrm{Li}, \mathrm{K}$. 2006. Effect of a dried bacillus culture on egg quality. Poult. Sci. 85: 364-368.

Zhang, W.H., Jiang, Y., Zhu, Q.F., Gao, F., Dai, S.F., Chen, J. and Zhou, G.H. 2011. Sodium butyrate maintains growth performance by regulating the immune response in broiler chickens. Br. poult. sci. 52(3):292-301.

\section{How to cite this article:}

Nataraja. D., V. Malathi, Jayanaik, H. C. Indresh and Sreedhara. J. N. 2020. Effect of Butyric Acid Supplementation on Growth Performance and Immune Response in Broilers Int.J.Curr.Microbiol.App.Sci. 9(02): 2422-2430. doi: https://doi.org/10.20546/ijcmas.2020.902.276 